\title{
The intensity of kelp harvesting shapes the population structure of the foundation species Lessonia trabeculata along the Chilean coastline
}

\author{
Adam Gouraguine ${ }^{1,2} \oplus$. Pippa Moore ${ }^{1,2} \cdot$ Michael T. Burrows $^{3} \cdot$ Eliana Velasco $^{4,5} \cdot$ Luis Ariz $^{4}$. Luis Figueroa-Fábrega ${ }^{6}$. \\ Rodrigo Muñoz-Cordovez ${ }^{7} \cdot$ Italo Fernandez-Cisternas ${ }^{7} \cdot$ Dan Smale $^{8} \cdot$ Alejandro Pérez-Matus $^{7}$
}

Received: 2 October 2020 / Accepted: 18 March 2021 / Published online: 11 April 2021

(c) The Author(s) 2021

\begin{abstract}
Kelp are foundation species that support high levels of biodiversity and, either directly or indirectly provide a wide range of ecological goods and services to human society. In recent decades, due to the high demand for kelp-derived products such as alginate, commercial wild harvesting has increased, leading to declines of kelp biomass in some regions. Chile accounts for $40 \%$ of the global kelp harvest, with the subtidal kelp, Lessonia trabeculata being one of the main target species. Currently, however, there is a lack of information on how different degrees of harvesting intensity, governed by distinct management regimes and their enforcement influences $L$. trabeculata populations. Here we examined the effect different management regimes, characterised by distinct levels of exploitation of kelp and kelp-associated fauna, have on L. trabeculata density and morphology along $\sim 1600 \mathrm{~km}$ of the Chilean coastline. The findings demonstrated that harvesting intensity likely influences both $L$. trabeculata density and morphology. Juvenile density of $L$. trabeculata was five times higher in the most harvestingaffected areas, while kelp morphology values, including holdfast diameter, number of stipes and total length, were always higher in the less-intensively harvested areas. Our study suggests that different degrees of protection can influence density and morphology of subtidal L. trabeculata populations, which in turn has important implications for the conservation of the kelp forest ecosystems and management of this important fishery.
\end{abstract}

\section{Introduction}

Kelp forests characterise subtidal rocky reefs in temperate and cold seas to a depth of up to ca. $40 \mathrm{~m}$ (Dayton et al.

Responsible Editor: F. Bulleri.

Reviewers: undisclosedexperts.

Alejandro Pérez-Matus

aperez@bio.puc.cl

Adam Gouraguine

adg31@aber.ac.uk

1 Institute of Biological, Environmental and Rural Sciences, Aberystwyth University, Aberystwyth SY23 3DA, UK

2 School of Natural and Environmental Sciences, Newcastle University, Newcastle-upon-Tyne NE1 7RU, UK

3 Scottish Association for Marine Science, Scottish Marine Institute, Oban PA37 1QA, UK

4 Departamento de Oceanografía y Medio Ambiente, Sección AMERB, Instituto de Fomento Pesquero (IFOP), Valparaíso, Chile 1985; Harrold and Pearse 1987; Vásquez 1997; Graham et al. 2007) and are distributed along ca. $25 \%$ of the global

5 Grupo de Investigación en Ciencias Oceanográficas, Universidad del Valle, Cali, Colombia

6 Laboratorio de Estudios Ecosistémicos, Escuela de Ingeniería y Negocios, Universidad Viña del Mar, Diego Portales 90, Viña del Mar, Chile

7 Subtidal Ecology Laboratory, Estación Costera de Investigaciones Marinas, Pontificia Universidad Católica de Chile, Casilla 114-D, Santiago, Chile

8 Marine Biological Association of the United Kingdom, Citadel Hill, Plymouth PL1 2PB, UK 
coastline (Krumhansl et al. 2016; Wernberg and Filbee-Dexter 2019). They form three-dimensional biogenic structures which offer habitat, shelter and food to a wide diversity of associated species, including species of commercial importance (Teagle et al. 2017; Lotze et al. 2019). As such, kelp species serve as foundation organisms that support high levels of biodiversity and provide a wide range of ecological goods (e.g. fisheries) and services (e.g. nutrient cycling, coastal protection) to human society (Dayton 1985; Teagle et al. 2017; Miller et al. 2018). These goods and services can be particularly important for artisanal coastal communities who often strongly rely on kelp forests for economic support via direct harvesting and trade of kelp or kelp-associated fish and shellfish (Vásquez et al. 2014; Wernberg and FilbeeDexter 2019).

Intense or prolonged harvesting can alter the structure and functioning of entire ecosystems (Pauly et al. 1998; Coleman and Williams 2002), including kelp forests (Vasquez and Santelices 1990; O'Connor and Anderson 2010; Geange 2014). For example, kelp harvesting can cause changes in population dynamics and loss of standing biomass at regional scales (Geange 2014), affect predator-prey interactions (Lorentsen et al. 2010), as well as impact kelp-associated species, including fish (O'Connor and Anderson 2010) and macroalgae (Vasquez and Santelices 1990). Impacts of harvesting at the population, community and ecosystem level can consequently impinge on the provision of ecological goods and services, with the magnitude of impacts dependent on harvesting methods, target species, and the scale, duration and frequency of harvesting (Waage-Nielsen et al. 2003; Steen et al. 2016; Lotze et al. 2019).

In recent decades, due to the high demand for kelpderived products such as alginates, commercial kelp harvesting has increased, leading to declines in kelp biomass and abundance in some regions (Wernberg et al. 2018). Currently, Chile accounts for approximately $40 \%$ of wild kelp harvesting globally (Lotze et al. 2019), where this fishery is one of the most important benthic fisheries in the country, directly or indirectly employing 13,000 people and landing up to 350,000 dry tonnes per year (valued at US\$90 million) (Vásquez et al. 2014). Prior to the twenty-first century, the fishery was mainly sustained by natural mortality, where plants cast ashore were collected by artisanal fishermen, with little-to-no impact on wild populations or ecological processes (Vásquez et al. 2012). However, by the early 2000s the kelp fishery became extractive, using specialised fishermen and harvesting equipment, with intensive harvesting of two species, Lessonia nigrescens complex, an intertidal species (see González et al. 2012) and Lessonia trabeculata, a subtidal species (Vásquez 2008). While L. nigrescens is relatively easily accessed and harvested from the shore, L. trabeculata harvesting is conducted by deploying boats and surface air-supplied divers. The divers use a metal hand-spike/pry bar tool, locally known as "barreta", which is modified for detachment of holdfasts of individual plants from the substrate. The detached plants are grouped and tied together underwater by a rope, which is subsequently used to haul the harvest onto the boat (personal observations). The harvested kelp is processed locally and then mainly exported to international markets as raw and dried material, where alginates are extracted for use in diverse manufacturing processes and industries (Vásquez 2016). Currently, the Chilean kelp fishery accounts for $\sim 10 \%$ of the global supply of alginates (Vásquez 2008).

In Chile, there is evidence to suggest that intertidal populations of $L$. nigrescens are somewhat resilient to harvesting, despite increased landings, with no significant changes in density, biomass and reproductive condition between areas of high harvesting pressure and areas of no or low harvesting pressure (Vásquez et al. 2012). Some findings, however, suggest that harvesting of $L$. nigrescens can have an effect on recruitment and morphology of the kelp (Oróstica et al. 2014). In contrast, there is paucity of information on the impact of increased harvesting on subtidal populations of $L$. trabeculata (but see Gelcich et al. (2012), Pérez-Matus et al. (2017)). Recent evidence, however, points to the expansion of deforested "barrens" in certain areas where L. trabeculata was once dominant and a subsequent lack of recovery from harvesting following fallow periods of 7 years (Pérez-Matus personal observations).

Along the coast of Chile, different management regimes operate; marine protected areas with no-take zones (MPAs), open access areas (OAs) with no protection and exclusive access areas of territorial user rights for fisheries (TURFs). Through the TURF policy, the Undersecretary of Fisheries assigns management of inshore benthic species to consortiums of local fishermen who manage the TURF via a committee (San Martín et al. 2010). First established in 1997 (San Martín et al. 2010), TURFs operate by granting tenure over a specific marine area to its local fishing organisation (Meltzoff et al. 2002). This system is distinguished from other marine spatial management approaches in that it grants explicit marine tenure rights within the context of comanagement (Castilla and Fernandez 1998). To be granted a TURF, Chilean artisanal fishing organisations must develop 5 -year management plans, which require approval from the Undersecretary of Fisheries. While fishermen are responsible for surveillance and enforcement of anti-poaching measures in TURFs, the level of protection varies between TURFs and depends on the fishermen involved (Meltzoff et al. 2002). Due to the different management regimes, a mosaic of discrete locations, characterised by varying degrees of harvesting pressures exists along the Chilean coast.

This study examined differences in densities and morphology of the kelp L. trabeculata, from locations subjected to different management regimes. The management regimes 
characterising these locations included no-take marine protected areas (MPAs) where no fishing activity takes place, TURFs with no kelp harvest (TURF-NKH) but a history of extraction of kelp-associated resources (e.g. many species of fish, the gastropods Concholepas concholepas and Fissurella spp.) and TURFs where harvesting of both kelp and kelp-associated fauna takes place (TURF-KH). It was hypothesised that different degrees of protection will influence both density and morphology of $L$. trabeculata, with the overall study aim being determining the relative importance harvesting intensity has in structuring $L$. trabeculata populations.

\section{Materials and methods}

\section{Study areas}

Sampling was carried out along $\sim 1600 \mathrm{~km}$ of Chilean coastline, from $36^{\circ} 09,277$ to $23^{\circ} 24,7^{\prime} \mathrm{S}$ (Fig. 1). Two
MPAs, two TURF-NKH and five TURF-KH were sampled between April and December of 2018. The MPAs, ECIM and Chañaral Reserva, were established in 1982 and 2005, respectively (ESM Table 1). ECIM belongs to a research station of the Pontifical Catholic University of Chile and was created with the aim of monitoring recovery processes and promoting research representative of the Chilean rocky shore ecosystems (Navarrete et al. 2010). Chañaral Reserva was awarded an MPA status as an essential habitat for the Humboldt penguin (Spheniscus humboldti) and the bottlenose dolphin (Tursiops truncatus) (Capella et al. 1999). TURF-NKH were established in 1997 and 2001 and while no kelp harvesting has taken place, benthic invertebrates and fish are regularly exploited within these TURFs (ESM Table 1). TURF-KH were established between 1997 and 2012 but have historically experienced exploitation of kelp and the associated benthic invertebrates and fish (ESM Table 1). Due to few available MPAs in Chile and logistical constraints reflected in large distances between different TURFs and year-round unfavourable sea conditions along

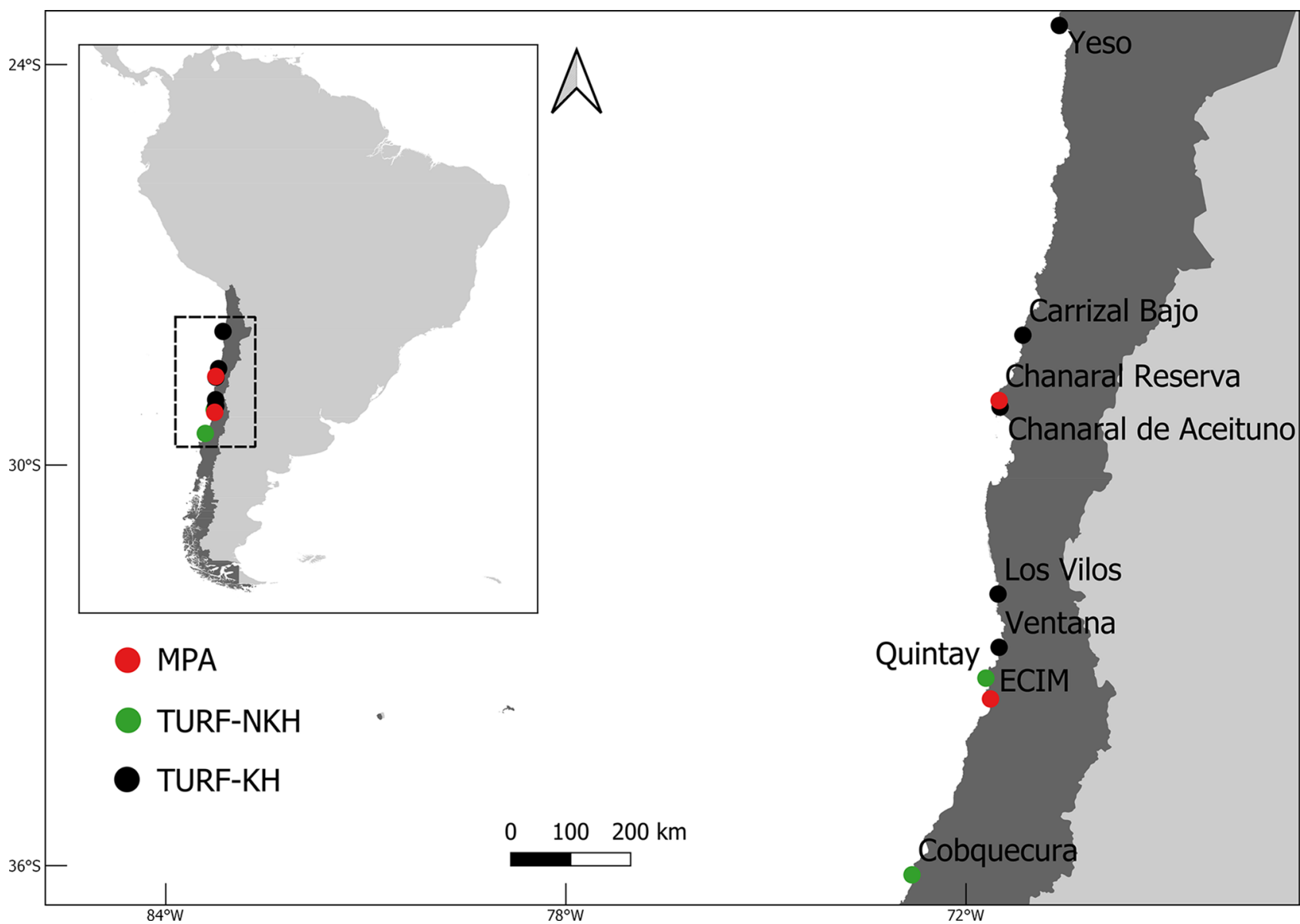

Fig. 1 Locations of the study sites. Marine Protected Areas (MPAs) are represented by red, TURFs with no kelp harvest (TURF-NKH) by green and TURFs where harvesting of both kelp and kelp-associated fauna takes place (TURF-KH) by black circles 
the exposed coast, we were unable to attain experimental design with an even replication of the suitable management regimes.

\section{Sampling methods}

At each site, L. trabeculata populations were sampled by SCUBA divers using $100 \times 2 \mathrm{~m}$ belt transects. The number of transects was determined based on the total length of the coast available at each site and ranged between 4 and 17 (81 transects in total) (ESM Table 2). All transects were orientated perpendicular to the coast, randomly placed within $L$. trabeculata forest, covering the upper and the lower depth limits of kelp (i.e. from 4 to $19 \mathrm{~m}$ below chart datum). The average site sampling depth ranged from 6.4 to $16 \mathrm{~m}$ (ESM Table 1). Within sites, the replicate transects were separated by a minimum horizontal distance of $100 \mathrm{~m}$. The density of kelp was recorded by counting the total number of holdfasts (representative of individual plants) for both juveniles and adults, found within each $100 \times 2 \mathrm{~m}$ belt transect. Individuals were classed as juveniles if their holdfast diameter
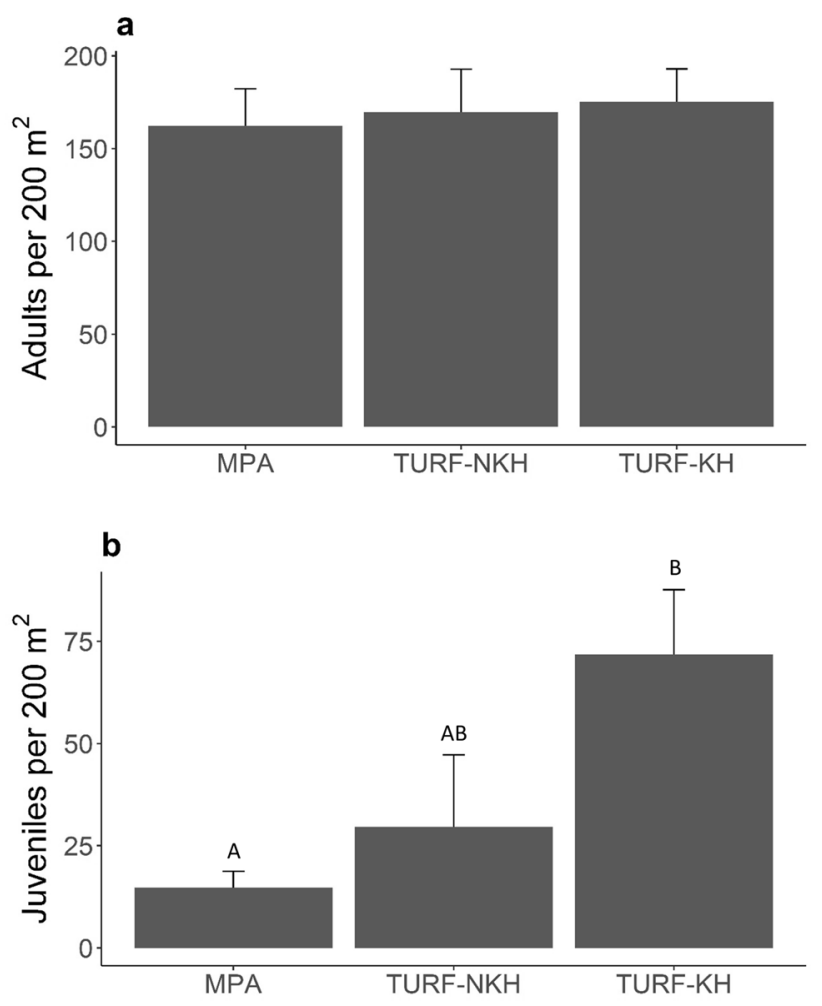

Fig. 2 Mean $( \pm \mathrm{SE})$ L. trabeculata kelp density under different management regimes (No-take marine protected areas (MPA), Territorial User Rights for Fisheries where kelp are not harvested but other benthic resources are (TURF-NKH) and Territorial User Rights for Fisheries where kelp and other benthic resources are harvested (TURF-KH)) for (a) adults and (b) juveniles. Different letters indicate significant differences $(P<0.05)$ among management regimes measured $<10 \mathrm{~cm}$, with individuals considered adult with a holdfast diameter of $\geq 10 \mathrm{~cm}$. Juveniles differed from adults in their morphology and length, and where generally characterised by the lack of stipes, with a small number of fronds $(<5)$ emerging directly from the holdfast. Adults had robust holdfasts from which, often, multiple, well developed stipes emerged with a large number of fronds attached. Kelp morphology was assessed using one $1 \mathrm{~m}^{2}$ quadrat placed every $10 \mathrm{~m}$ on the alternate side of the transect ( $n=10$ quadrats per transect). In the quadrats, maximum holdfast diameter, number of stipes and total length of each holdfast were recorded. All sites were dominated by L. trabeculata, with an absence of other large canopy-forming macroalgae. In general, sites were characterised by extensive, low profile/rugosity, stable bedrock, dominated by kelp stands and an understorey assemblage comprising encrusting coralline algae and a relatively low cover of foliose red algae.

\section{Statistical analyses}

Poisson generalized linear mixed-effects models (GLMMs) were used to test the degree of influence of different management regimes (MPA, TURF-NKH, TURF-KH) on $L$. trabeculata density of adults and juveniles and morphology of adults (holdfast size, number of stipes and total length). All GLMMs were random intercept models where the random factor was site. Through this modelling approach the influence of sites on the dependent variable was taken into account, allowing for site-independent evaluation of the influence of the management regimes on kelp at a broader scale (Zuur et al. 2009). Post-hoc simultaneous inference in general parametric models tests for linear hypotheses in generalized linear mixed models were run to test the statistical significance of the variables and $L$. trabeculata using the package multicomp in R (Hothorn et al. 2008). All model data were analysed with the package lme 4 in $\mathrm{R}$ (Bates et al. 2015; R Core Team 2017).

\section{Results}

There was no statistically significant difference in adult $L$. trabeculata density between management regimes (Fig. 2a, Table 1). Juvenile density was, however, significantly different and approximately 5 times lower in the MPAs compared to the TURF-KH (Table 1). While not statistically significant, the density of juveniles in TURF-NKH was approximately half that of the TURF-KH, as was the density of juveniles in the MPAs compared to TURF-NKH (Fig. 2b).

Statistically significant differences for holdfast diameter and number of stipes were observed between the MPAs and TURF-KH, as well as between TURF-KH and TURFNKH (Fig. 3, Table 2). For all morphological measures, 
Table 1 GLMMs exploring the effect of management regimes on the density of adult and juvenile L. trabeculata

\begin{tabular}{|c|c|c|c|c|c|}
\hline & \multicolumn{3}{|c|}{ Deviance } & \multicolumn{2}{|c|}{ Residual degrees of freedom } \\
\hline \multicolumn{6}{|l|}{ Adult } \\
\hline Model & \multicolumn{3}{|c|}{6152.20} & \multicolumn{2}{|l|}{77} \\
\hline \multicolumn{6}{|l|}{ Coefficient } \\
\hline Random & Groups & & iance & \multicolumn{2}{|c|}{ Standard deviation } \\
\hline \multicolumn{6}{|l|}{ Adult } \\
\hline Site & 9 & \multicolumn{2}{|c|}{0.07} & \multicolumn{2}{|c|}{0.27} \\
\hline Fixed & Degrees of freedom & Est & Standard error & $z$ & $P$ \\
\hline \multicolumn{6}{|l|}{ Adult } \\
\hline TURF-KH-TURF-NKH & 1 & 0.02 & 0.23 & 0.08 & 1.00 \\
\hline MPA-TURF-NKH & 1 & -0.09 & 0.27 & -0.35 & 0.94 \\
\hline \multirow[t]{2}{*}{ MPA-TURF-KH } & 1 & -0.11 & 0.23 & -0.49 & 0.88 \\
\hline & \multicolumn{2}{|c|}{ Deviance } & & \multicolumn{2}{|c|}{ Residual degrees of freedom } \\
\hline \multicolumn{6}{|l|}{ Juvenile } \\
\hline Model & \multirow{2}{*}{\multicolumn{2}{|c|}{6950.10}} & & \multirow{2}{*}{\multicolumn{2}{|c|}{77}} \\
\hline \multicolumn{2}{|l|}{ Coefficient } & & & & \\
\hline Random & \multicolumn{2}{|l|}{ Groups } & Variance & \multicolumn{2}{|c|}{ Standard deviation } \\
\hline \multicolumn{6}{|l|}{ Juvenile } \\
\hline Site & 9 & \multicolumn{2}{|c|}{0.37} & \multicolumn{2}{|c|}{0.61} \\
\hline Fixed & Degrees of freedom & Estimate & Standard error & $z$ & $P$ \\
\hline \multicolumn{6}{|l|}{ Juvenile } \\
\hline TURF-KH-TURF-NKH & 1 & 0.57 & 0.51 & 1.12 & 0.50 \\
\hline MPA-TURF-NKH & 1 & -0.61 & 0.61 & -0.99 & 0.58 \\
\hline MPA-TURF-KH & 1 & -1.17 & 0.51 & -2.29 & $<0.05$ \\
\hline
\end{tabular}

All the significant coefficients are highlighted in bold $(P<0.05)$

For each of the models deviance and residual degrees of freedom are given. The coefficients are shown with the number of groups or degrees of freedom, along with the associated standard deviation or standard error, estimate, $z$ value $(z)$ and $p$ value $(P)$

the highest values were observed in the MPAs, followed by TURF-NKH and then TURF-KH (Fig. 3). Mean holdfast size and length were greater by almost $1 / 4$ in the MPAs than in TURF-KH, while the mean number of stipes was twice as high. In TURF-NKH compared to TURF-KH, the number of stipes was higher by $1 / 3$, mean holdfast diameter was approximately $1 / 5$ greater, while the mean total length was similar.

\section{Discussion}

Our findings highlight the influence different degrees of protection can have on density and morphology of subtidal $L$. trabeculata populations, which has significant implications for the conservation of kelp forest ecosystems and the management of this important fishery.

Similar to what has been observed in other studies along the Chilean coast (Vásquez et al. 2012; Pérez-Matus et al.
2017), the density of adult kelp was not affected by harvesting pressure. Conversely, we did observe differences in juvenile densities between the different management regimes, with the highest densities of juveniles found at the most exploited sites. Harvesting of $L$. trabeculata usually results in thinning or clearing of 6-10 m diameter patches of adult kelp (personal observations). It is likely that space freed up from the harvesting of adult plants increases the density of juveniles as the absence of large holdfasts of harvested adults plants creates benthic space for settlement of new recruits and allows for their subsequent survival due to the decreased shading by an otherwise dense canopy, resulting in a juvenilised forest (Figueroa-Fábrega et al. 2017). In our case, while the density of adults was similar across management regimes, in the MPAs and TURF-NKH they were larger and had more canopy area due to higher number of stipes. Consequently, in addition to reduced substrate availability, resulting from larger holdfasts, these plants would have reduced light penetration in the MPAs and TURF-NKH 

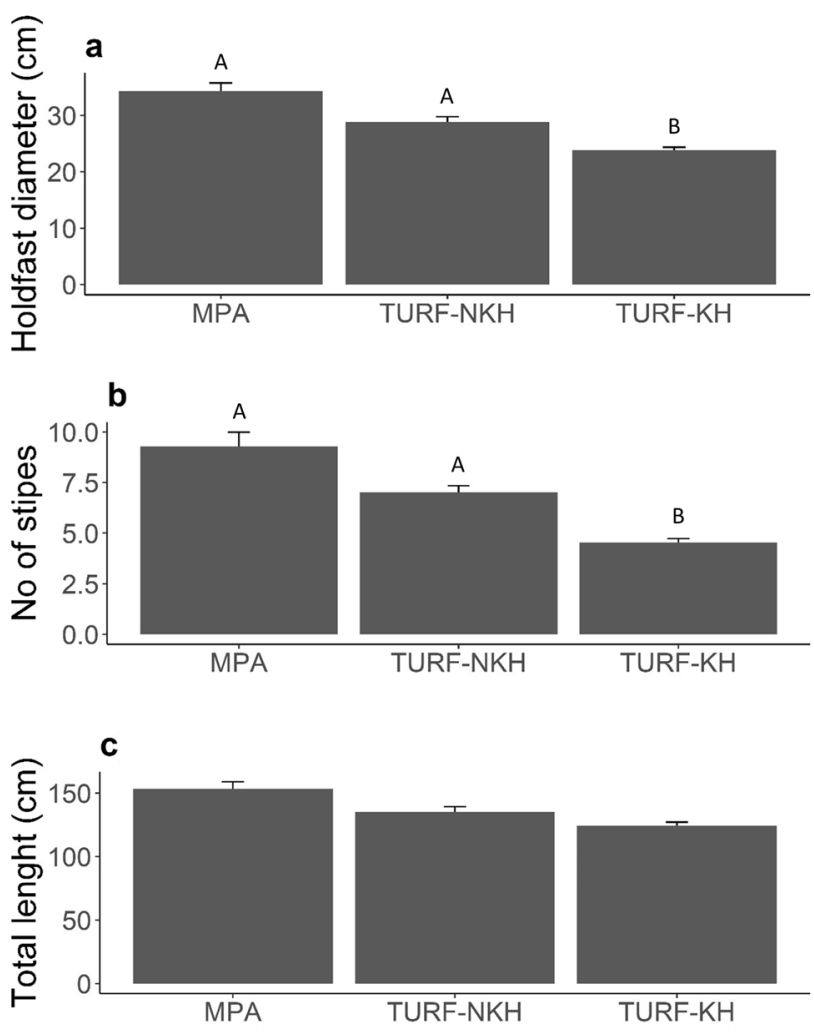

Fig. 3 Mean $( \pm$ SE) adult L. trabeculata (a) holdfast diameter, (b) number of stipes and (c) total length under different management regimes (No-take marine protected areas (MPA), Territorial User Rights for Fisheries where kelp are not harvested but other benthic resources are (TURF-NKH) and Territorial User Rights for Fisheries where kelp and other benthic resources are harvested (TURF-KH)). Letters denote significant differences $(P<0.05)$ between management regimes

compared to the TURF-KH, in which less dense kelp allowed for more light, favouring juvenile recruitment. This has previously been seen in $L$. trabeculata where strong recruitment and high densities of juveniles were observed in intensely harvested areas with no evidence of recruitment in non-harvested areas, where the population consisted mainly of adult individuals (Westermeier et al. 2017). Similarly, Westermeier et al. (2019) reported rapid colonisation by the new recruits of the intertidal kelp, L. nigrescens, following a complete removal of the adult individuals. However, this pattern is not consistent with Pérez-Matus et al. (2017) and Vásquez et al. (2012) who failed to find a link between harvesting intensity and juvenile density of $L$. trabeculata and L. nigrescens, respectively.

We recorded significant increases in holdfast diameter and the number of stipes at sites with greater protection. TURF-KH were characterised by "juvenilised" forests dominated by smaller plants (smaller holdfasts, fewer stipes and shorter plants), therefore harbouring fewer harvestable and less valuable plants. This is, perhaps, unsurprising considering that larger individuals are targeted by the fishery due to a higher alginate content (Peteiro 2018). Stark differences observed in the kelp forest structure in TURF-KH suggest that the fisheries in these areas are less productive due to high intensity harvest, yielding lower crop compared to nonkelp harvested areas. Previous studies on post-harvesting recovery of $L$. trabeculata have suggested slow recovery. For example, after 12 months of post-harvest recovery, kelp individuals had only grown to a total length of between 40 and $50 \mathrm{~cm}$, with a holdfast diameter of $8 \mathrm{~cm}$ (Westermeier et al. 2017). Furthermore, following $>2$ years recovery, holdfasts had not attained $20 \mathrm{~cm}$ in diameter, which according to bio-ecological recommendations by Vásquez (2008), is the minimum harvestable size, indicating that kelp plants were still unsuitable for harvest (Westermeier et al. 2017). Hence, while kelp extraction may not lead to a reduction in adult kelp density, intense harvesting may shift population structure towards smaller individuals, which are less value to the industry. Kelp harvesting in the TURF-KH is often carried out annually, over several consecutive years, with no fallow periods that would allow for kelp recovery between the harvests (ESM Table 3). As a result, if the extraction, at the current rate, continues within TURF-KH, the value of $L$. trabeculata and the kelp fishery itself will likely diminish with subsequent harvests, with implications for fishing communities reliant on it as a primary source of income. This is likely to be of most concern to communities that mange and rely on TURFs for their livelihoods. Population dynamics of $L$. trabeculata evidenced in our study are different from other commercially exploited kelps in Chile. For example, Macrocystis pyrifera reach harvestable size in less than 6 months (Westermeier et al. 2014), while L. nigrescens can attain harvestable size within 10 months following recruitment into cleared areas (Westermeier et al. 2019). As such, specific management plans tailored for each macroalgal species are needed to achieve sustainability. For $L$. trabeculata, due to its seemingly slower growth rates, longer-term studies are necessary to determine recovery rates following harvesting under different environmental conditions. In addition, different TURF committees use different harvesting and fallowing regimes (pers. comm.). Future work should also investigate if particular harvesting regimes promote faster recovery of $L$. trabeculata. In the meantime, we suggest that fishers should adopt the precautionary principle and include fallow periods of 3 years or more between harvesting events and/or adopt harvesting approaches that may promote recovery by leaving potential parental stock nearby at the same time as increasing habitable space and light penetration.

There were no observed differences in density or morphology between the MPAs and TURF-NKH, which was somewhat expected considering kelp harvesting has not 
Table 2 GLMMs exploring the effect of management regimes on the morphology (holdfast diameter, number of stipes and total length) of adult L. trabeculata

Deviance

4855.5

Holdfast

Model

Coefficient

\begin{tabular}{|c|c|c|c|c|c|}
\hline \multirow{2}{*}{$\frac{\text { Random }}{\text { Holdfast }}$} & \multicolumn{2}{|l|}{ Groups } & \multicolumn{2}{|l|}{ Variance } & Standard deviation \\
\hline & & & & & \\
\hline Site & 9 & \multicolumn{2}{|r|}{0.01} & \multicolumn{2}{|c|}{0.10} \\
\hline Fixed & Degrees of freedom & Estimate & Standard error & $z$ & $P$ \\
\hline \multicolumn{6}{|l|}{ Holdfast } \\
\hline TURF-KH-TURF-NKH & 1 & 0.22 & 0.09 & 2.51 & $<0.05$ \\
\hline MPA-TURF-NKH & 1 & -0.12 & 0.10 & -1.19 & 0.46 \\
\hline \multirow[t]{2}{*}{ MPA-TURF-KH } & 1 & -0.34 & 0.09 & -3.91 & $<0.05$ \\
\hline & \multicolumn{2}{|c|}{ Deviance } & & \multicolumn{2}{|c|}{ Residual degrees of freedom } \\
\hline \multicolumn{6}{|l|}{ Stipes } \\
\hline Model & \multicolumn{2}{|c|}{3516.0} & & \multicolumn{2}{|l|}{561} \\
\hline \multicolumn{6}{|l|}{ Coefficient } \\
\hline Random & Groups & & Variance & \multicolumn{2}{|c|}{ Standard deviation } \\
\hline \multicolumn{6}{|l|}{ Stripes } \\
\hline Site & 9 & \multicolumn{2}{|r|}{0.04} & \multicolumn{2}{|c|}{0.20} \\
\hline Fixed & Degrees of freedom & Estimate & Standard error & $z$ & $P$ \\
\hline \multicolumn{6}{|l|}{ Stripes } \\
\hline TURF-KH-TURF-NKH & 1 & 0.45 & 0.17 & 2.60 & $<0.05$ \\
\hline MPA-TURF-NKH & 1 & -0.29 & 0.21 & -1.42 & 0.33 \\
\hline \multirow[t]{2}{*}{ MPA-TURF-KH } & 1 & -0.75 & 0.17 & -4.28 & $<0.05$ \\
\hline & \multicolumn{2}{|c|}{ Deviance } & & \multicolumn{2}{|c|}{ Residual degrees of freedom } \\
\hline \multicolumn{6}{|l|}{ Length } \\
\hline Model & \multirow{2}{*}{\multicolumn{2}{|c|}{14012.0}} & & \multirow{2}{*}{\multicolumn{2}{|c|}{561}} \\
\hline \multicolumn{2}{|l|}{ Coefficient } & & & & \\
\hline Random & Groups & & Variance & & deviation \\
\hline Length & & & & & \\
\hline Site & 9 & & 0.01 & & \\
\hline Fixed & Degrees of freedom & Estimate & Standard error & $z$ & $P$ \\
\hline Length & & & & & \\
\hline TURF-KH-TURF-NKH & 1 & 0.13 & 0.10 & 1.29 & 0.40 \\
\hline MPA-TURF-NKH & 1 & -0.09 & 0.12 & -0.72 & 0.75 \\
\hline MPA-TURF-KH & 1 & -0.22 & 0.10 & -2.15 & 0.08 \\
\hline
\end{tabular}

All the significant coefficients are highlighted in bold $(P<0.05)$

For each of the models deviance and residual degrees of freedom are given. The coefficients are shown with the number of groups or degrees of freedom, along with the associated standard deviation or standard error, estimate, $z$ value $(z)$ and $p$ value $(P)$

taken place in these TURFs. Interestingly, there was a non-significant trend of increasing juvenile density and decreasing holdfast diameter, stipe number and total size
Residual degrees of freedom

561

\section{.05}

0.46 s.t.s 
kelp-associated fauna on TURF-NKH kelp populations. A number of commercially important fish species commonly exploited within TURF-NKH (e.g. Pinguipes chilensis, Cheilodactylus variegatus, Semicossyphus darwini) are some of the most important predators of the main grazers of L. trabeculata (Tetrapygus niger and Tegula tridentata) along the Chilean coast (Vasquez 1993). It has been demonstrated that these grazers affect both density and morphology of L. trabeculata (Vásquez and Buschmann 1997). As a result, removal of kelp-associated fish from TURFs-NKH can lead to increases in grazers and could be, at least partly, responsible for the subtle differences in the kelp populations observed between MPAs and TURF-NKH. Evidence from other studies along the Chilean coast demonstrates higher densities of grazers and higher rates of grazing on L. trabeculata in areas with increased exploitation of some carnivorous fish species (Pérez-Matus et al. 2017). In general, along the coast of Chile, higher numbers of L trabeculata grazers are found at exploited sites compared to unexploited ones (Oróstica et al. 2014; Pérez-Matus et al. 2017).

In future studies, it will be important to consider both the direct effects of kelp harvesting and the indirect effects of harvesting kelp-associated species when managing these ecosystems that are important, both for supporting biodiversity and human well-being. Furthermore, it is noteworthy that along the entire Chilean coast only two MPAs exist, both of which we used as study sites. While additional MPAs would have also been optimal for the study's experimental design, detection of the most important differences of the impacts of kelp harvesting are owed precisely to the inclusion of these MPAs in the study. This highlights the need for creation of further MPAs in the region, which, as we here demonstrate, are paramount for detecting current harvestinduced changes in kelp populations and can provide an important baseline for monitoring future changes.

In summary, we demonstrate that the level of protection is likely to play an important role in structuring L. trabeculata populations in Chile. Given that the degree of protection from harvesting can influence aspects of kelp population structure, such as plant morphology and densities of juveniles, it is likely that harvesting also indirectly influences habitat provision for associated faunal communities, ecological resilience and rates of primary productivity. Accordingly, careful management of L. trabeculata within TURFs is paramount to provide the dependent artisanal fishing communities with a long-term sustainable income.

Supplementary Information The online version contains supplementary material available at https://doi.org/10.1007/s00227-021-03870-7.

Acknowledgements AG, PM, MB, RM, DS and APM were funded by a NERC-Newton Fund-ANID (Agencia Nacional de Investigacion) Latin American Biodiversity Grant NE/S011692/1. DS. is also supported by a UKRI Future Leaders Fellowship (MR/S032827/1). We thank the two anonymous reviewers for their comments, which helped improve the manuscript.

Funding AG, PM, MB, RM, DS and APM were funded by a NERCNewton Fund-ANID (Agencia Nacional de Investigacion) Latin American Biodiversity Grant NE/S011692/1. D.S. is also supported by a UKRI Future Leaders Fellowship (MR/S032827/1).

Availability of data and material The data used in this study are available from the corresponding author upon request.

Code availability Codes used in this study are available from the corresponding author upon request.

\section{Declarations}

Conflict of interest The authors have no conflicts of interest to declare that are relevant to the content of this article.

Ethical approval This is an observational study and no ethical approval is required.

Consent for publication All authors have agreed to the submitted version of the manuscript and give their consent for its publication.

Research permits For sampling in the MPAs permissions were granted under R. Ex. $\mathrm{N}^{\circ} 2231$ by the Undersecretary of Fisheries Chile, Sernapesca N1 8086 and are available on request.

Open Access This article is licensed under a Creative Commons Attribution 4.0 International License, which permits use, sharing, adaptation, distribution and reproduction in any medium or format, as long as you give appropriate credit to the original author(s) and the source, provide a link to the Creative Commons licence, and indicate if changes were made. The images or other third party material in this article are included in the article's Creative Commons licence, unless indicated otherwise in a credit line to the material. If material is not included in the article's Creative Commons licence and your intended use is not permitted by statutory regulation or exceeds the permitted use, you will need to obtain permission directly from the copyright holder. To view a copy of this licence, visit http://creativecommons.org/licenses/by/4.0/.

\section{References}

Bates D, Maechler M, Bolker B, Walker S (2015) Fitting linear mixedeffects models using lme4. J Stat Softw 67:1-48

Capella J, Vilina Y, Gibbons J (1999) Observación de cetáceos en isla Chañaral y nuevos registros para el área de la Reserva Nacional Pingüino de Humboldt, norte de Chile. Estud Ocean 18:57-54

Castilla JC, Fernandez M (1998) Small-scale benthic fisheries in Chile: on co-management and sustainable use of benthic invertebrates. Ecol Appl 8:124-132

Coleman FC, Williams SL (2002) Overexploiting marine ecosystem engineers: potential consequences for biodiversity. Trends Ecol Evol 17:40-44

Dayton PK (1985) The structure and regulation of some south american kelp communities. Ecol Monogr 55:447-468

Figueroa-Fábrega L, Padilla T, Herrera MJ, Ariz L, Silva-Haun R (2017) Evolución de parámetros poblacionales y estado 
poblacional de las algas pardas del género Lessonia (Laminariales, Phaeophyceae) en áreas de manejo y explotación de recursos bentónicos del norte de Chile. An del Mus Hist Nat Valparaiso 30:61-70

Geange SW (2014) Growth and reproductive consequences of photosynthetic tissue loss in the surface canopies of Macrocystis pyrifera (L.) C Agardh. J Exp Mar Bio Ecol 453:70-75

Gelcich S, Fernández M, Godoy N, Canepa A, Prado L, Castilla JC (2012) Territorial user rights for fisheries as ancillary instruments for marine coastal conservation in Chile. Conserv Biol 26:1005-1015

González A, Beltrán J, Hiriart-Bertrand L, Flores V, de Reviers B, Correa JA, Santelices B (2012) Identification of cryptic species in the Lessonia nigrescens complex (phaeophyceae, laminariales). J Phycol 48:1153-1165

Graham MH, Vásquez JA, Buschmann AH (2007) Global ecology of the giant kelp Macrocystis: From ecotypes to ecosystems. Oceanogr Mar Biol 45:39-88.

Harrold C, Pearse J (1987) The ecological role of echinoderms in kelp forests. In: Echinoderm Studies. Balkema, pp 137-233

Hothorn T, Bretz F, Westfall P (2008) Simultaneous inference in general parametric models. Biom J 50:346-363

Krumhansl KA, Okamoto DK, Rassweiler A, Novak M, Bolton JJ, Cavanaugh KC, Wernberg T, Anderson RJ, Barrett NS, Buschmann AH, Carr MH, Watson J, Witman JD, Byrnes JEK (2016) Global patterns of kelp forest change over the past halfcentury. Proc Natl Acad Sci 113:13785-13790

Lorentsen SH, Sjøtun K, Grémillet D (2010) Multi-trophic consequences of kelp harvest. Biol Conserv 143:2054-2062

Lotze HK, Milewski I, Fast J, Kay L, Worm B (2019) Ecosystem-based management of seaweed harvesting. Bot Mar 62(5):395-409

Meltzoff SK, Lichtensztajn YG, Stotz W (2002) Competing visions for marine tenure and co-management: genesis of a marine management area system in Chile. Coast Manag 30:85-99

Miller RJ, Lafferty KD, Lamy T, Kui L, Rassweiler A, Reed DC (2018) Giant kelp, Macrocystis pyrifera, increases faunal diversity through physical engineering. Proc R Soc B. https://doi.org/ 10.1098/rspb.2017.2571

Navarrete SA, Gelcich S, Castilla JC (2010) Long-term monitoring of coastal ecosystems at Las Cruces, Chile: Defining baselines to build ecological literacy in a world of change. Rev Chil Hist Nat

O'Connor KC, Anderson TW (2010) Consequences of habitat disturbance and recovery to recruitment and the abundance of kelp forest fishes. J Exp Mar Bio Ecol 386:1-10

Oróstica MH, Aguilera MA, Donoso GA, Vásquez JA, Broitman BR (2014) Effect of grazing on distribution and recovery of harvested stands of Lessonia berteroana kelp in northern Chile. Mar Ecol Prog Ser 511:71-82

Pauly D, Christensen V, Dalsgaard J, Froese R, Torres F (1998) Fishing down marine food webs. Science 279:860-863

Pérez-Matus A, Carrasco SA, Gelcich S, Fernandez M, Wieters EA (2017) Exploring the effects of fishing pressure and upwelling intensity over subtidal kelp forest communities in Central Chile

Peteiro C (2018) Alginate production from marine macroalgae, with emphasis on kelp farming. In: Moradali MF, Bernd HAR (eds) Alginates and their biomedical applications. Springer, Singapore

R Core Team (2017) R: A language and environment for statistical computing.
San Martín G, Parma A, Orensanz JM (2010) The chilean experience with territorial use rights in Fisheries. In: Handbook of Marine Fisheries Conservation and Management. Oxford University Press, pp 324-337

Steen H, Moy FE, Bodvin T, Husa V (2016) Regrowth after kelp harvesting in Nord-Trøndelag, Norway. ICES J Mar Sci J du Cons 73:2708-2720

Teagle H, Hawkins SJ, Moore PJ, Smale DA (2017) The role of kelp species as biogenic habitat formers in coastal marine ecosystems. J Exp Mar Bio Ecol 492:81-98

Vasquez JA (1993) Abundance, distributional patterns and diets of main herbivorous and carnivorous species associated to Lessonia trabeculata kelp beds in northern Chile. Ser Ocas Univ Catol del Norte 2:213-229

Vasquez JA, Santelices B (1990) Ecological effects of harvesting Lessonia (Laminariales, Phaeophyta) in central Chile. Hydrobiologia 204-205:41-47

Vásquez JA (2008) Production, use and fate of Chilean brown seaweeds: re-sources for a sustainable fishery. J Appl Phycol 20:457-467

Vásquez JA (2016) The brown seaweeds fishery in Chile. In: Heimo M (ed) Fisheries and aquaculture in the modern world. Intech

Vásquez J, Buschmann AH (1997) Herbivore-kelp interactions in Chilean subtidal communities: a review. Rev Chil Hist Nat 70:41-52

Vásquez JA, Piaget N, Vega JMA (2012) The Lessonia nigrescens fishery in northern Chile: "how you harvest is more important than how much you harvest." J Appl Phycol 24:417-426

Vásquez JA, Zuñiga S, Tala F, Piaget N, Rodríguez DC, Vega JMA (2014) Economic valuation of kelp forests in northern Chile: values of goods and services of the ecosystem. J Appl Phycol 26:1081-1088

Waage-Nielsen E, Christie H, Rinde E (2003) Short-term dispersal of kelp fauna to cleared (kelp-harvested) areas. Hydrobiologia 503:77-91

Wernberg T, Filbee-Dexter K (2019) Missing the marine forest for the trees. Mar Ecol Prog Ser 612:209-215

Wernberg T, Krumhansl K, Filbee-Dexter K, Pedersen MF (2019) Status and Trends for the World's Kelp Forests. In: World Seas: an Environmental Evaluation, Second Edi. Academic Press, pp $57-78$

Westermeier R, Murúa P, Patiño DJ, Muñoz L, Atero C, Müller DG (2014) Repopulation techniques for Macrocystis integrifolia (Phaeophyceae: Laminariales) in Atacama, Chile. J Appl Phycol 26:511-518

Westermeier R, Murúa P, Patiño DJ, Müller DG (2017) Population biology and long-term mariculture studies in the brown alga Lessonia trabeculata in Atacama, Chile. J Appl Phycol 29:2267-2275

Westermeier R, Murúa P, Patiño DJ, Manoli G, Müller DG (2019) Evaluation of kelp harvest strategies: recovery of Lessonia berteroana (Phaeophyceae, Laminariales) in Pan de Azucar, Atacama, Chile. J Appl Phycol 31:575-585

Zuur A, Ieno E, Walker N, Saveliev A, Smith G (2009) Mixed effects models and extensions in ecology with R. Springer Science+Business Media

Publisher's Note Springer Nature remains neutral with regard to jurisdictional claims in published maps and institutional affiliations. 